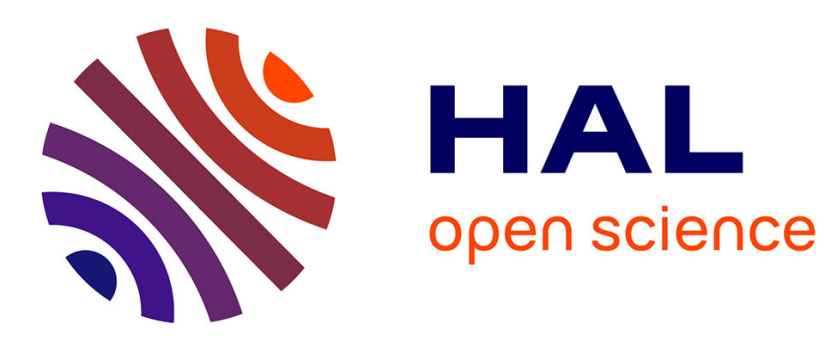

\title{
Intake and digestibility of four forages by Ilamas and sheep
}

R Cordesse, M Inesta, Jl Gaubert

\section{To cite this version:}

R Cordesse, M Inesta, Jl Gaubert. Intake and digestibility of four forages by Ilamas and sheep.

Annales de zootechnie, 1992, 41 (1), pp.70-70. hal-00888790

\section{HAL Id: hal-00888790 \\ https://hal.science/hal-00888790}

Submitted on 1 Jan 1992

HAL is a multi-disciplinary open access archive for the deposit and dissemination of scientific research documents, whether they are published or not. The documents may come from teaching and research institutions in France or abroad, or from public or private research centers.
L'archive ouverte pluridisciplinaire HAL, est destinée au dépôt et à la diffusion de documents scientifiques de niveau recherche, publiés ou non, émanant des établissements d'enseignement et de recherche français ou étrangers, des laboratoires publics ou privés. 


\title{
Intake and digestibility of four forages by llamas and sheep
}

\author{
R Cordesse, M Inesta, JL Gaubert \\ ENSA-INRA, Place Viala, 34060 Montpellier Cedex 1, France
}

There is still very little known on the capacity of llamas to ingest and digest forages. We measured these capacities on 4 forages in comparison with sheep.

Five to 6 male castrated llamas at the end of their growth period $(78 \mathrm{~kg}$ live-weight), and 5 adult male castrated merinos $(55 \mathrm{~kg}$ LW) were successively fed, ad libitum, during periods of 5-6 weeks, 4 forages of different qualities (table I). Supplementary minerals and vitamins were supplied to satisfy needs. The digestibility was measured by total collection of feces on the last 10 days of each period.

Sheep had to be discarded for insufficient intake during the 2 periods where straw and straw + urea were offered. Llama intake of lucerne hay and of $\mathrm{NH}_{3}$ treated straw was respectively $30 \%$ and $20 \%$ lower than that of sheep. The digestibility of organic matter (dOM) and nitrogen of these 2 forages were similar for the 2 species. In llamas, intake and digestibility of straw increased (respectively $6.4 \mathrm{~g} \mathrm{DM} / \mathrm{kg} 0.75$ and 3 points dOM) consecutively to urea supply, as commonly observed in other ruminants.

In conclusion, llamas seem to be less influenced in their food intake by forage quality than sheep, but have the same digestive capacity, at least when medium digestibility forages $(\approx 60 \%)$ are given. In contrast, they could digest poor forages more extensively, as suggested by the dMO (53 \%) measured on wheat straw, which was much higher than the values commonly observed in sheep.

Table I. Characteristics of the 4 forages; dry matter (DM) intake $\left(9 / \mathrm{kg}^{0,75}\right)$, and organic matter $(\mathrm{OM})$ and nitrogen $(\mathrm{N})$ digestibility $(\%)$.

\begin{tabular}{|c|c|c|c|c|c|c|}
\hline & \multicolumn{2}{|c|}{ Lucerne hay } & \multicolumn{2}{|c|}{$\begin{array}{l}\mathrm{NH}_{3} \text {-treated } \\
\text { wheat straw }\end{array}$} & $\begin{array}{c}\text { Wheat } \\
\text { straw + } \\
1.4 \% \text { urea }\end{array}$ & $\begin{array}{l}\text { Wheat } \\
\text { straw }\end{array}$ \\
\hline $\begin{array}{l}\mathrm{N} \text { content } \\
(\% \text { DM) } \\
\text { DM digestibility }\end{array}$ & \multicolumn{2}{|c|}{$\begin{array}{l}2.76 \\
54.2\end{array}$} & \multicolumn{2}{|c|}{$\begin{array}{l}1.72 \\
50.7\end{array}$} & $\begin{array}{c}1.45 \\
-\end{array}$ & $\begin{array}{l}0.73 \\
29.7\end{array}$ \\
\hline $\begin{array}{c}\text { Species } \\
(n)\end{array}$ & $\underset{(6)}{\text { Llamas }}$ & $\begin{array}{l}\text { Sheep } \\
\text { (5) }\end{array}$ & $\underset{(6)}{\operatorname{Llamas}}$ & $\begin{array}{c}\text { Sheep } \\
(5)\end{array}$ & $\underset{(5)}{\text { Llamas }}$ & $\underset{(5)}{\text { Llamas }}$ \\
\hline DM intake & $58.9 \pm 4.1$ & $83.4 \pm 6.2$ & $49.2 \pm 4.5$ & $62.0 \pm 2.8$ & $41.9 \pm 2.8$ & $36.5 \pm 1.9$ \\
\hline OM digestibility & $61.0 \pm 1.1$ & $61.2 \pm 1.1$ & $60.5 \pm 1.3$ & $59.0 \pm 3.2$ & $\begin{array}{l}58.0 \pm 1.2 \\
54.9\end{array}$ & $\begin{array}{c}55.0 \pm 2.6 \\
\approx 0\end{array}$ \\
\hline
\end{tabular}

'Measured with fungi cellulase. 